\title{
Characterization of four plasmids harboured in a Lactobacillus brevis strain encoding a novel bacteriocin, brevicin 925A, and construction of a shuttle vector for lactic acid bacteria and Escherichia coli
}

Correspondence

Masanori Sugiyama

sugi@hiroshima-u.ac.jp
Received 2 August 2008

Revised 16 January 2009

Accepted 19 January 2009
Takaomi Wada, ${ }^{1}$ Masafumi Noda, ${ }^{1,2}$ Fumi Kashiwabara, ${ }^{1}$ Hyung Joon Jeon, ${ }^{1}$ Ayano Shirakawa, ${ }^{1}$ Hironori Yabu, ${ }^{3}$ Yasuyuki Matoba, ${ }^{1}$ Takanori Kumagai ${ }^{1}$ and Masanori Sugiyama ${ }^{1,2}$

\author{
${ }^{1}$ Department of Molecular Microbiology and Biotechnology, Graduate School of Biomedical \\ Sciences, Hiroshima University, Kasumi 1-2-3, Minami-ku, Hiroshima 734-8551, Japan \\ ${ }^{2}$ Frontier Center for Microbiology, Hiroshima University, Kasumi 1-2-3, Minami-ku, Hiroshima \\ 734-8551, Japan \\ ${ }^{3}$ Hiroshima Prefectural Food Technology Research Center, Hijiyama-Honmachi 12-70, Minami-ku, \\ Hiroshima 732-0816, Japan
}

\begin{abstract}
In this study we isolated over 250 lactic acid bacteria (LAB) candidates from fruit, flowers, vegetables and a fermented food to generate an LAB library. One strain, designated 925A, isolated from kimchi (a traditional Korean fermented dish made from Chinese cabbage) produced a novel type of bacteriocin, brevicin $925 \mathrm{~A}$, which is effective against certain LAB, including strains of Lactobacillus, Enterococcus, Streptococcus, Bacillus and Listeria. Strain 925A, identified as Lactobacillus brevis, harboured at least four plasmids and we determined the entire nucleotide sequence of each one. The four plasmids were designated pLB925A01-04, and have molecular sizes of 1815, 3524, 8881 and $65037 \mathrm{bp}$, respectively. We obtained bacteriocin non-producing derivatives by treatment of strain $925 \mathrm{~A}$ with novobiocin. All of these derivatives, which were susceptible to their own antibacterial product, lost the largest plasmid, pLB925A04, suggesting that the genes for bacteriocin biosynthesis (breB and breC) and immunity (bre $E$ ) are located on pLB925A04. The partial amino acid sequence of purified brevicin 925A and sequence analysis of pLB925A04 showed that breB is the structural gene for brevicin 925A. We constructed a shuttle vector (pLES003, $6134 \mathrm{bp}$ ) that can replicate in both Escherichia coli and LAB such as Lactobacillus plantarum, Lb. brevis, Lactobacillus helveticus, Lactobacillus hilgardii and Enterococcus hirae. To determine the function of gene breE, which displays no significant similarity to any other sequences in the BLAST search database, the gene was inserted into pLES003. A pLB925A04-cured derivative transformed with pLES003 carrying breE acquired immunity to brevicin $925 \mathrm{~A}$, suggesting that bre $E$ encodes an immunity protein.
\end{abstract}

\section{INTRODUCTION}

Lactic acid bacteria (LAB) is the generic name given to bacteria that produce large amounts of lactic acid by fermentation of various sugars and other carbohydrates. LAB have been suggested to improve the gut microflora and are regarded as potentially beneficial bacteria with

Abbreviations: $L A B$, lactic acid bacteria; $R C R$, rolling-circle replication. The GenBank/EMBL/DDBJ accession numbers for the sequences reported in this paper are AB370334, AB370335, AB370336, AB370337 and AB370338. therapeutic effects for the health of the host, such as antiallergy properties and intestinal homeostasis (Adolfsson et al., 2004; Cross et al., 2001; Heyman, 2000; Meydani \& Ha, 2000), and are often termed 'probiotics' (Guarner \& Schaafsma, 1998).

$\mathrm{LAB}$ are roughly classified into two groups according to the source of isolation. One group comes from animal sources, such as fermented raw milk, cheese and intestines. The other group is isolated from plant sources, such as grasses, silage, vegetables and fruit (Lavermicocca et al., 2005; Okada, 2002; van Hylckama Vlieg et al., 2006). Although 
Lactococcus lactis is a primary constituent of starter cultures for many fermented dairy products, the same species can also be isolated from plant material. Our interest is in the molecular and phenotypic diversity found in animal- and plant-derived LAB.

In the present study, we isolated 250 LAB from fruit, flowers, vegetables and a fermented dish to generate an LAB library. In the plant-derived library, a strain numbered 925A, and identified as Lactobacillus brevis, was isolated from kimchi (a traditional Korean fermented dish made from Chinese cabbage). This strain produces a bacteriocin (brevicin 925A) which inhibits the growth of Listeria monocytogenes and Streptococcus mutans. Since Lb. brevis 925A harbours at least four plasmids, we determined whether the bacteriocin-biosynthetic cluster is located on any of these plasmids or the chromosome by analysing the entire nucleotide sequence of the four plasmids.

In addition, to develop one of these plasmids as a genetic tool for $\mathrm{LAB}$, we created a shuttle vector carrying the replication origins of pLB925A03 and pUC19. The constructed vector, pLES003, was able to replicate in Escherichia coli and some LAB. Bacteriocin-susceptible derivatives transformed with pLES003 carrying breE, which displays no significant similarity to any other sequences in the BLAST search database, acquired immunity to brevicin 925A, suggesting that breE encodes an immunity protein.

\section{METHODS}

Media and growth conditions. MRS broth (Merck) was used for the growth of all LAB. E. coli, Staphylococcus and Bacillus strains were cultured in LB medium (Sambrook et al., 1989), and the Listeria strains were cultured in tryptic soy broth medium supplemented with $0.3 \%$ yeast extract (TSBYE). E. coli $\mathrm{DH} 5 \alpha$ and plasmid pUC19 were used for the cloning experiments. When required, ampicillin $\left(100 \mu \mathrm{g} \mathrm{ml}^{-1}\right)$, erythromycin $\left(300 \mu \mathrm{g} \mathrm{ml}^{-1}\right.$ for E. coli, and $5 \mu \mathrm{g} \mathrm{ml}^{-1}$ for $\mathrm{LAB}$ ) and $1.5 \%$ agar were added.

Assay of antibacterial activity. The antibacterial activity of bacteriocins produced by LAB was determined by the agar diffusion method (Klaenhammer, 1988; van Reenen et al., 1998). Bacteriocincontaining supernatant fluid, obtained by centrifugation of LAB cultures, was adjusted to $\mathrm{pH} 7.0$, membrane-filtered and used for the antibacterial assay. The bacteria listed in Table 2 were used as test organisms to investigate the antibacterial spectra at a concentration of $10^{6}$ cells $\mathrm{ml}^{-1}$.

Isolation and identification of bacteriocin-producing bacteria. Each strain of LAB isolated from plants was inoculated into MRS broth and incubated anaerobically at 28 or $37{ }^{\circ} \mathrm{C}$ for $2-3$ days. An aliquot of the culture was plated onto MRS broth supplemented with $1.5 \%$ agar and incubated at the given temperature for 2-3 days. Each colony generated on the plate was re-spread onto fresh MRS agar medium for colony purification. We carried out Gram-staining, and organic acid- and catalase-production tests on the purified colonies prior to species identification.

To identify the LAB candidates, we analysed the sugar fermentation profile of each strain using an API 50 CHL kit (bioMérieux). Furthermore, the entire 16S rDNA sequence of the collected LAB was determined as described previously (Hiraishi, 1992; Lane, 1991;
Weisburg et al., 1991) and compared with that of typical LAB obtained from the DNA Data Bank of Japan (DDBJ) website (www.ddbj.nig.ac.jp/Welcome-e.html). LAB species were identified by analysis of the sequence alignment using the CLUSTAL $\mathrm{W}$ program (http://clustalw.ddbj.nig.ac.jp/top-e.html).

Purification of bacteriocin. To purify bacteriocin produced extracellularly by $L b$. brevis $925 \mathrm{~A}$, the bacterium was grown in 11 MRS broth at $28{ }^{\circ} \mathrm{C}$ for $24 \mathrm{~h}$. After removal of the cells by centrifugation at $3000 \mathrm{~g}$ for $10 \mathrm{~min}$, the resulting supernatant was applied to a Toyopearl SP-650S column $(2.5 \times 4.5 \mathrm{~cm}$; Tosoh $)$ equilibrated with $20 \mathrm{mM}$ sodium phosphate buffer ( $\mathrm{pH} 5.8$ ), and the excess protein was eluted with a 15-bed volume of the same buffer. After the column was washed with a 5-bed volume of $20 \mathrm{mM}$ sodium phosphate buffer containing $0.15 \mathrm{M} \mathrm{NaCl}$, the antibacterial peptide was eluted with a 7-bed volume of the same buffer containing $1 \mathrm{M} \mathrm{NaCl}$. Ammonium sulfate was added to the eluate until the concentration reached $0.42 \mathrm{M}$, and the resulting solution was applied to a Phenyl-Sepharose column $(1.0 \times 10 \mathrm{~cm}$; Amersham Biosciences $)$ equilibrated with $20 \mathrm{mM}$ sodium phosphate buffer ( $\mathrm{pH}$ 5.8) containing $1 \mathrm{M} \mathrm{NaCl}$ and $0.42 \mathrm{M}$ ammonium sulfate. The column was then washed with a 6-bed volume of an equilibrating buffer. The antibacterial fraction was eluted with a $1-0 \mathrm{M} \mathrm{NaCl}$ and $0.42-0 \mathrm{M}$ ammonium sulfate linear gradient in the same buffer and finally eluted with water containing $0.1 \%$ trifluoroacetic acid. The resulting fractions were collected, and a portion of each fraction was tested for antibacterial activity. The active fractions were desalted with PD-10 (Amersham Biosciences) and dried in vacuo. The fraction containing antibacterial activity was stored at $-20{ }^{\circ} \mathrm{C}$ until use. During these purification steps, the antibacterial activity contained in each fraction was evaluated using Lactobacillus plantarum NBRC 3070 as a test organism.

Amino acid sequencing of bacteriocin. The peptide was rehydrated, extracted from an SDS-PAGE gel, digested with trypsin and then concentrated in a centrifugal vacuum concentrator. After desalting of the concentrate using Zip-TipC18 tips (Millipore), the samples were eluted in $50 \%$ acetonitrile $/ 0.1 \%$ trifluoroacetic acid, and a $1 \mu \mathrm{l}$ portion of the eluate was mixed with a matrix solution ( $1: 1$ ratio) and applied on a MALDI target plate. Acquisition of MS data was performed on an Ultraflex MALDI-TOF/TOF mass spectrometer (Bruker Daltonics). After acquisition and mass axis recalibration, database searches were performed using the MASCOT program (Matrix Science).

Production of bacteriocin non-producing derivatives. Bacteriocin non-producing derivatives from $L b$. brevis $925 \mathrm{~A}$ were isolated according to the method described by Chin et al. (2005) with a slight modification: an aliquot of the culture broth was seeded (approx. $10^{5}$ c.f.u. $\mathrm{ml}^{-1}$ ) in MRS broth containing 5, 10, 20, 40 and $50 \mu \mathrm{g}$ novobiocin $\mathrm{ml}^{-1}$, which is an inhibitor of bacterial DNA gyrase. After cultivation at $28{ }^{\circ} \mathrm{C}$ for $2-3$ days, a portion of the cultures was plated onto fresh MRS agar and anaerobically incubated at the same temperature for 2-3 days. The bacteriocin-sensitive derivatives were selected from the colonies generated on the plate, and plasmid profiles of each colony were investigated. A bacteriocinsensitive derivative from strain $925 \mathrm{~A}$, designated $L$ b. brevis $925 \mathrm{~A}-\Delta 02 /$ 03/04, which harbours plasmid pLB925A01 but not pLB925A02, pLB925A03 and pLB925A04, was used as a host for the plasmid introduction experiments.

DNA preparation and manipulation. A plasmid from E. coli was isolated by a standard method (Sambrook et al., 1989). Chromosomal DNA and plasmids from $L b$. brevis were isolated from cells grown at $28{ }^{\circ} \mathrm{C}$ for $24 \mathrm{~h}$ as described previously (Hiraishi, 1992) with slight modifications. Cells collected by centrifugation were washed with a glucose-EDTA buffer $(50 \mathrm{mM}$ glucose, $25 \mathrm{mM}$ Tris/HCl, $10 \mathrm{mM}$ 
EDTA, $\mathrm{pH}$ 8.0) and resuspended in the same buffer containing $10 \mu \mathrm{g}$ RNase $\mathrm{ml}^{-1}$ (Roche), $0.4 \mathrm{mg}$ achromopeptidase $\mathrm{ml}^{-1}$ (Wako Pure Chemicals) and $4 \mathrm{mg}$ lysozyme $\mathrm{ml}^{-1}$ (Wako Pure Chemicals). After cell lysis by incubation at $37^{\circ} \mathrm{C}$ for $1 \mathrm{~h}$, protein denaturation and chloroform/isoamylalcohol extraction were carried out. The chromosomal and plasmid DNAs were concentrated by PEG precipitation. If necessary, the plasmid was purified by $\mathrm{CsCl}_{2}$ density-gradient centrifugation.

DNA sequencing. Nucleotide sequencing was achieved with the $\mathrm{ABI}$ PRIZM 310 genetic analyser using the BigDye Terminator v1.1 Cycle Sequencing kit according to the manufacturer's protocol (Applied Biosystems). Genetic analysis was performed using ATGC and GENETYX software (Genetyx Corporation). ORFs were predicted using an ORF finder tool at NCBI (www.ncbi.nlm.nih.gov/gorf/gorf.html). Homology searches were performed with the BLAST algorithm (Altschul et al., 1990) utilizing the non-redundant database provided by NCBI.

Nucleotide sequence analysis of plasmids. pLB925A01 and pLB925A02 DNA, extracted from agarose gels, was digested with NheI and EcoRI, respectively, and subcloned into the same site of pUC19. In the case of pLB925A03, the PstI-digested $0.6 \mathrm{~kb}$ fragment was subcloned into pUC19. Another region of pLB925A03 was amplified by PCR using pLB925A03 as a template with sense $\left(5^{\prime}\right.$-CTTATGAAAAGTCAAAGGAACTGCCTAT- $3^{\prime}$ ) and antisense ( $5^{\prime}$-TGATTTTCTACGTGCGAAATTGTTGTGA-3') primers designed on the basis of the $0.6 \mathrm{~kb}$ Pst $\mathrm{I}$-digested sequence. The nucleotide sequence of the amplified $8.2 \mathrm{~kb}$ DNA was determined by the direct sequence method.

Because the size of pLB925A04 was expected to be quite large, the bacteriocin gene cluster region was first subcloned into pUC19. Restriction-digested pLB925A04 DNA was fractionated using $0.5 \%$ agarose gel electrophoresis and transferred to a Hybond-N+ membrane (GE Healthcare) using a standard protocol (Sambrook et al., 1989). A DNA probe (222 bp) for cloning of the bacteriocin biosynthetic gene was PCR-amplified with sense (5'-ATGGAGAAATTCGCAGTGTT- ${ }^{\prime}$ ) and antisense (5'-TTATTTGTTATTTAGGCAGC- $3^{\prime}$ ) primers, using the $L b$. brevis $925 \mathrm{~A}$ plasmid DNA as a template. These primers were designed on the basis of the nucleotide sequence of the gene encoding plantaricin 1.25 $\gamma$ (PRF accession no. 2607194A). PCR was conducted under the following conditions: 1 cycle of $5 \mathrm{~min}$ at $96{ }^{\circ} \mathrm{C}, 15 \mathrm{~s}$ at $58{ }^{\circ} \mathrm{C}$ and $30 \mathrm{~s}$ at $72{ }^{\circ} \mathrm{C}$ followed by 29 cycles of $1 \mathrm{~min}$ at $96^{\circ} \mathrm{C}, 15 \mathrm{~s}$ at $58{ }^{\circ} \mathrm{C}$ and $30 \mathrm{~s}$ at $72{ }^{\circ} \mathrm{C}$, and finally a $7 \mathrm{~min}$ extension period at $72{ }^{\circ} \mathrm{C}$. Labelling of the probe and detection were performed using an AlkPhos direct labelling and detection kit (GE Healthcare), according to the manufacturer's instructions. The hybridized DNA fragment was extracted from the agarose gel and ligated into the same site of pUC19. The chimaeric plasmid was introduced into E. coli $\mathrm{DH} 5 \alpha$ and screened using a colony hybridization technique (Sambrook et al., 1989). After determination of the nucleotide sequence around the bacteriocin biosynthetic gene, the entire nucleotide sequence of pLB925A04 was determined using inverse PCR (Sambrook \& Russell, 2001). For inverse PCR, Lb. brevis 925A plasmid DNA was digested with an appropriate single restriction enzyme and purified by the phenol/ chloroform extraction method. The purified DNA fragments were self-ligated using a DNA Ligation kit (TaKaRa) at a concentration of about $1 \mathrm{ng} \mu^{-1}$, and a $4 \mu \mathrm{l}$ portion of the self-ligated mixture was used as a template for inverse PCR together with properly designed primer pairs. The nucleotide sequence of the PCR product was determined by the direct sequencing method.

Construction of the shuttle vector pLES003. The shuttle vector pLES003 contains the erythromycin resistance gene together with the replication origins of pLB925A03 and pUC19. The drug-resistance gene from plasmid pH2515 (Shimizu-Kadota et al., 1991), expressed in Enterococcus, was obtained by PCR amplification using sense (5'-CATATGTAGAAGCAAACTTAAGAGTGTGTT- ${ }^{\prime}$ ') and antisense (5'-CATATGATAGACGGTTTTTCGCCCTTTGAC-3') primers (NdeI sites underlined). The amplified DNA was digested with $\mathrm{NdeI}$ and inserted into the same site of pUC19 to yield pre-pLES003. Next, the ori region of pLB925A03 was amplified by PCR using pLB925A03 as a template with sense ( $5^{\prime}$-GACGTCCGTCTGTCGCTACATAATTATACGAA-3') and antisense (5'-GACGTCAGTCTGCCTATTCCTGCTTGAAAA-3') primers (AatII sites underlined). The PCR product was digested with AatII and inserted into AatII-digested pre-pLES003 to yield pLES003.

Construction of a plasmid carrying breE. The breB promoter region was amplified by PCR using sense (5'-GCTCTAGAGGCTGTCTGTCCTTTA-3'; XbaI site underlined) and antisense (5'-AAGGATCCCGCTCTCCCTCTTATTT-3'; BamHI site underlined) primers. The amplified DNA fragment was digested with $X b a \mathrm{I}$ and $B a m \mathrm{HI}$, and inserted into the same sites of pLES003. Next, the breE gene was amplified by PCR using sense (5'-AAGGATCCATGAAAGCTATTATGAAA- $3^{\prime}$; BamHI site underlined) $\overline{\text { and }}$ antisense (5'-CCGAATTCTCAATAAATACGTTTGAT-3'; EcoRI site underlined) primers. The amplified DNA was digested with BamHI and EcoRI and subcloned into the same sites of pLES003 with the breB promoter to yield pLES003/breE.

Transformation of LAB. The preparation of competent cells from bacteriocin non-producing derivatives and other LAB was conducted according to the methods described by Alegre et al. (2004) and Dunny et al. (1991). Competent cells $(0.1 \mathrm{ml})$ mixed with plasmid DNA were placed into a $0.2 \mathrm{~cm}$ electroporation cuvette from a Gene Pulser apparatus (Bio-Rad) and held on ice for $5 \mathrm{~min}$. After pulsing under specific conditions (field strength, $12.5 \mathrm{kV} \mathrm{cm}^{-1}$; capacitance, $25 \mu \mathrm{F}$; resistance, $400 \Omega$ ), the cell suspension was immediately diluted with $1 \mathrm{ml}$ MRS broth and then incubated at 28 or $37^{\circ} \mathrm{C}$ for $5 \mathrm{~h}$. A portion of the cell suspension was placed on selective media and incubated anaerobically at 28 or $37^{\circ} \mathrm{C}$ for $1-2$ days.

\section{RESULTS}

\section{Identification of bacteriocin-producing strains}

In this study we isolated many LAB candidates from fruit, flowers and vegetables to generate an LAB library. Out of 328 candidate strains, 250 (about $76 \%$ ) were classified as $\mathrm{LAB}$ on the basis of their $16 \mathrm{~S}$ rDNA sequence (data not shown). Most of the LAB isolates from vegetables and flowers were classified in the genera Enterococcus and Lactococcus, respectively, whereas strains from fruit and other plants belonged to a wide range of genera (Table 1). We found that the culture broth of one strain, which was isolated from kimchi and designated 925A, possessed antibacterial activity. Carbohydrate utilization profiles, analysed with API $50 \mathrm{CHL}$, suggested that strain $925 \mathrm{~A}$ is a strain of $L b$. brevis. The entire $16 \mathrm{~S}$ rDNA sequence also exhibited the highest level of similarity with the sequences of Lb. brevis R097 (accession no. AF515219, 99.67\% identity), R066 (AF515220, 99.736\%) and ATCC 367 (CP000416, 99.802\%), confirming that strain $925 \mathrm{~A}$ is indeed a strain of $L b$. brevis.

As listed in Table 2, the antibacterial activity produced in the 925A liquid culture was effective against the strains of 
Table 1. Origin of isolates of plant-associated $L A B$

\begin{tabular}{|lrrrrc|}
\hline \multirow{2}{*}{ Genus } & \multicolumn{5}{c|}{ No. of isolates from: } \\
\cline { 2 - 6 } & Fruit & Vegetables & Flowers & $\begin{array}{r}\text { Fermented } \\
\text { vegetables }\end{array}$ & $\begin{array}{c}\text { Other } \\
\text { plants }\end{array}$ \\
\hline Enterococcus & 29 & 46 & 1 & 0 & 6 \\
Lactobacillus & 27 & 0 & 0 & 12 & 4 \\
Lactococcus & 7 & 0 & 44 & 0 & 9 \\
Leuconostoc & 7 & 2 & 7 & 0 & 2 \\
Streptococcus & 14 & 1 & 2 & 0 & 0 \\
Pediococcus & 16 & 0 & 0 & 0 & 0 \\
Other genera & 8 & 4 & 0 & 0 & 2 \\
\hline
\end{tabular}

Bacillus, Enterococcus, Lactobacillus, Lactococcus, Listeria and Streptococcus. Interestingly, it was effective against Listeria monocytogenes, a food pathogen, and an oral bacterium, S. mutans. In addition, the antibacterial activity

Table 2. Antibacterial activity of brevicin $925 \mathrm{~A}$

\begin{tabular}{|c|c|c|}
\hline Species & Indicator strain ${ }^{\star}$ & Activity \\
\hline \multicolumn{3}{|l|}{ Gram-positive bacteria } \\
\hline Bacillus coagulans & NBRC 12583 & ++ \\
\hline Bacillus cereus & ATCC 11778 & - \\
\hline Bacillus licheniformis & NBRC 12195 & - \\
\hline Bacillus sphaericus & NBRC 15095 & - \\
\hline Bacillus stearothermophilus & NBRC 13737 & - \\
\hline Bacillus subtilis & ATCC 6633 & - \\
\hline Enterococcus hirae & NBRC 3128 & + \\
\hline Enterococcus faecalis & NBRC 12964 & - \\
\hline Lactobacillus curvatus & NBRC 15884 & - \\
\hline Lactobacillus delbrueckii subsp. lactis & NBRC 3073 & - \\
\hline Lactobacillus helveticus & NBRC 15019 & - \\
\hline Lactobacillus hilgardii & NBRC 15886 & +++ \\
\hline Lactobacillus sakei & NBRC 15893 & ++ \\
\hline Lactobacillus plantarum & NBRC 3070 & ++ \\
\hline Lactococcus lactis subsp. cremoris & NBRC 100676 & ++ \\
\hline Listeria monocytogenes & ATCC 7644 & - \\
\hline Listeria monocytogenes & ATCC 15313 & + \\
\hline Pediococcus pavulus & NBRC 100673 & - \\
\hline Staphylococcus aureus & NBRC 12732 & - \\
\hline Staphylococcus aureus & IID 1677 (MRSA) & - \\
\hline Staphylococcus epidermidis & NBRC 12993 & - \\
\hline Streptococcus mutans & MT 8148R & + \\
\hline Streptococcus sobrinus & ATCC 27607 & - \\
\hline Streptococcus equinus & NBRC 12553 & - \\
\hline \multicolumn{3}{|l|}{ Gram-negative bacteria } \\
\hline Escherichia coli & NBRC 3972 & - \\
\hline Salmonella enteritidis & NBRC 3313 & - \\
\hline Pseudomonas aeruginosa & NBRC 13275 & - \\
\hline
\end{tabular}

*ATCC, American Type Culture Collection, Manassas, VA, USA; IID, Laboratory Culture Collection, Institute of Medical Sciences, University of Tokyo, Japan; NBRC, Biological Resource Center, National Institute of Technology and Evaluation (NITE), Kisarazushi, Chiba, Japan; MRSA, meticillin-resistant Staphylococcus aureus. was resistant to heat treatment at $100{ }^{\circ} \mathrm{C}$ for $10 \mathrm{~min}$, but not to proteases such as proteinase $\mathrm{K}$ and trypsin (data not shown), suggesting that the antibacterial substance is a polypeptide of the bacteriocin type. In this study, the antibacterial polypeptide from strain 925A was designated brevicin 925A.

\section{Purification and characterization of brevicin 925A}

Brevicin 925A was purified from the supernatant fluid from an overnight culture of strain $925 \mathrm{~A}$ by cationexchange and hydrophobic chromatography. Since PhenylSepharose chromatography yielded a single peak for antibacterial activity (Fig. 1), the amino acid sequence of brevicin 925A was determined by de novo sequence analysis after peptide mass fingerprint analysis and an MS/MS ion search were performed (data not shown). The partial amino acid sequence of the $\mathrm{N}$-terminal region of brevicin 925A was KKKKKYTGPNYR.

\section{Plasmid profile and curing experiments}

The agarose gel electrophoresis profile suggests that $L b$. brevis $925 \mathrm{~A}$ has at least four plasmids (Fig. 2a). We named these four plasmids pLB925A01-04 in order of size from small to large. To determine whether the genes for bacteriocin biosynthesis and immunity to their own antibiotic product are located on the plasmids, plasmidcuring experiments were conducted on Lb. brevis 925A. We observed that bacteriocin non-producing derivatives lost one to four of the plasmids randomly, but all of the derivatives lost the largest plasmid pLB925A04 with similar frequency. In addition, these derivatives also lost immunity

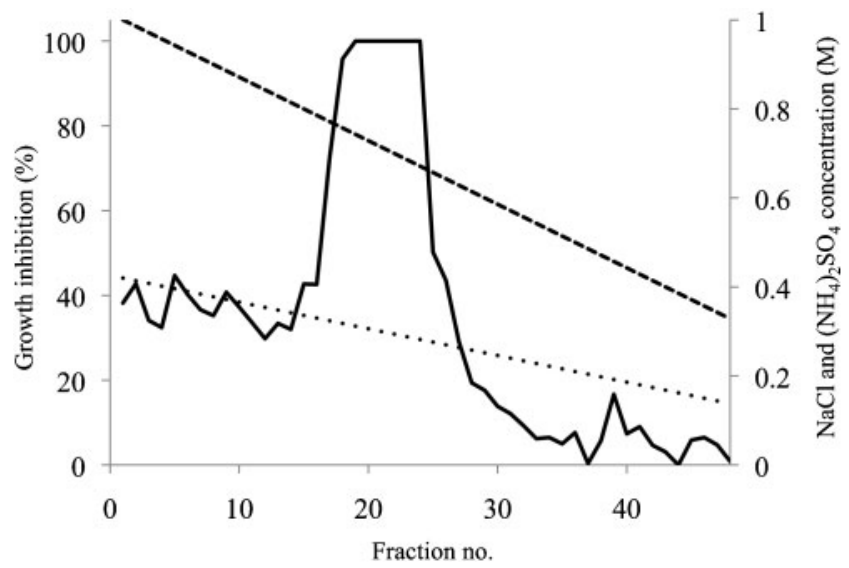

Fig. 1. Hydrophobic chromatography of partially purified brevicin 925A recovered from cation-exchange chromatography. Each fraction obtained by chromatography was assayed for antibacterial activity. Antibacterial activity (growth inhibition, solid line) was measured using Lb. plantarum NBRC 3070 as a test organism. Dashed line, $\mathrm{NaCl}$ concentration; dotted line, $\left(\mathrm{NH}_{4}\right)_{2} \mathrm{SO}_{4}$ concentration. 
(a)

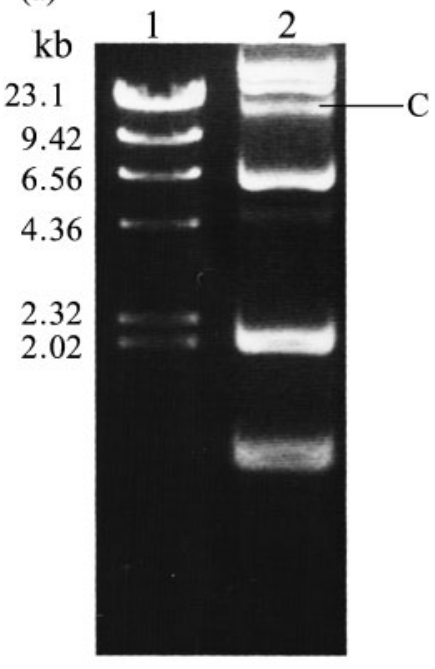

(b)
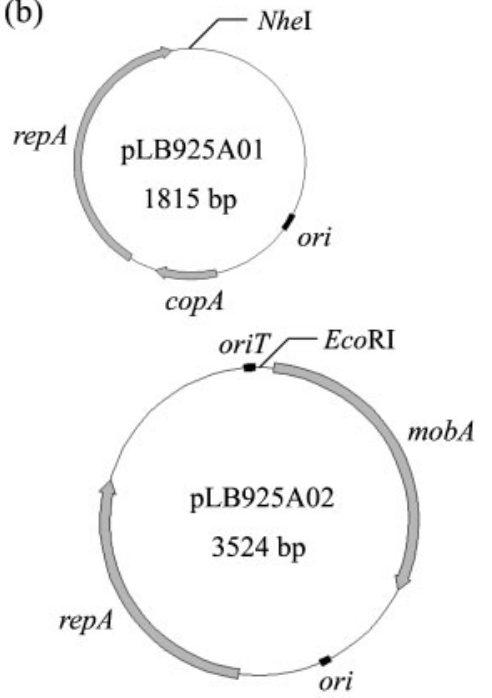

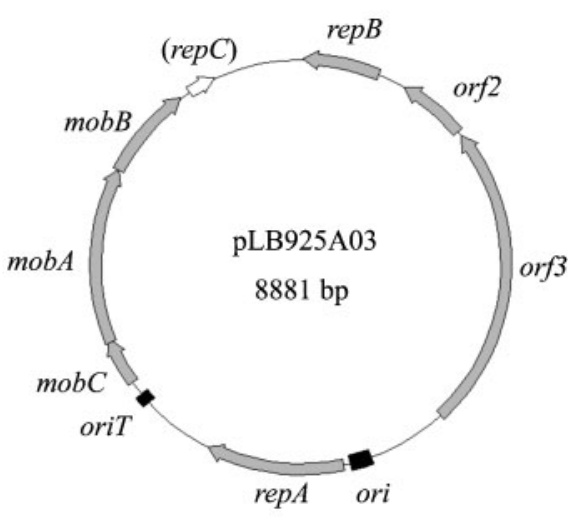

(c)

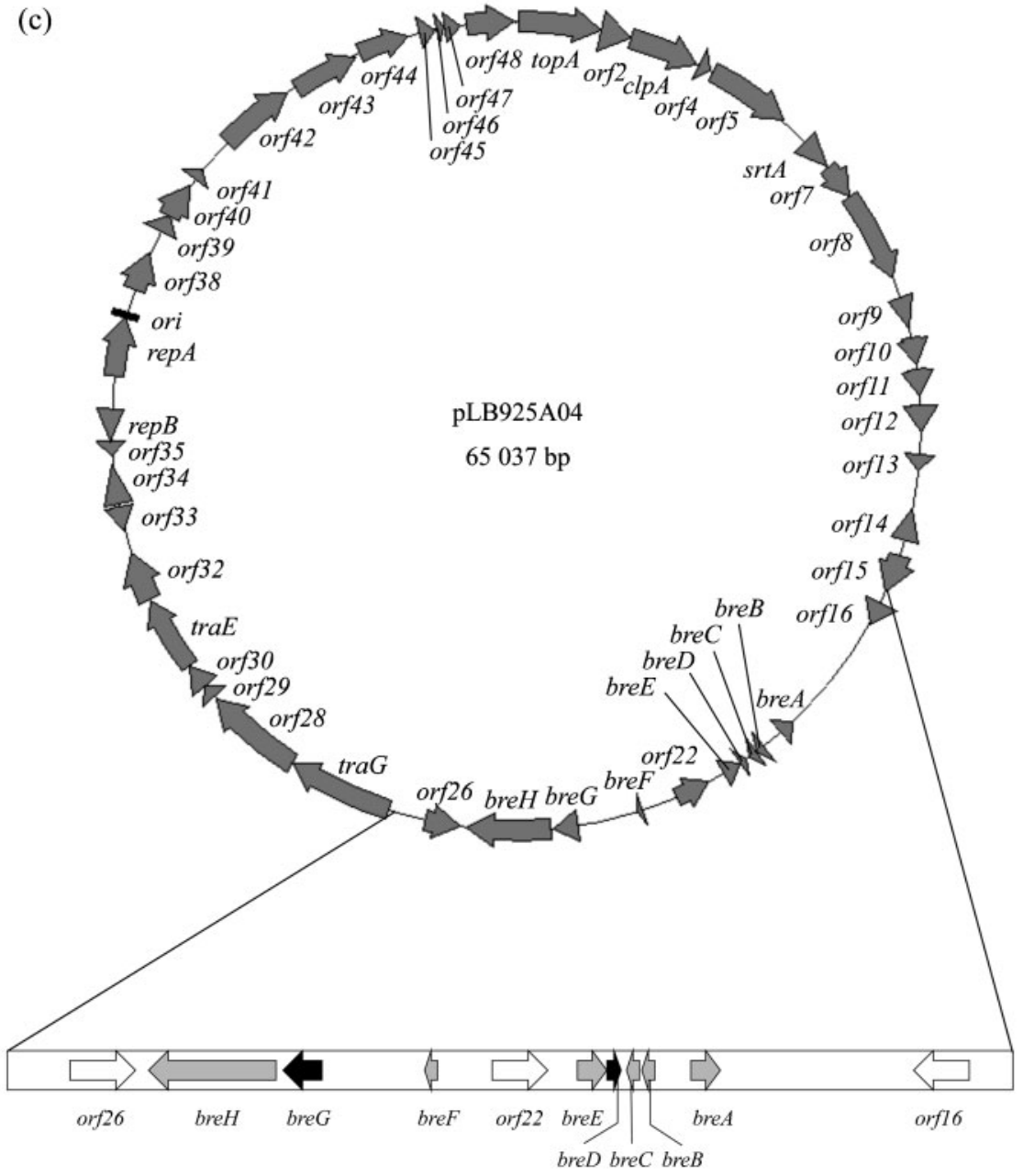

Fig. 2. Profiles of plasmids harboured in $L b$. brevis 925A. (a) Electrophoretic profile of plasmids separated on a $0.5 \%(w / v)$ agarose gel. Lanes: 1, $\lambda$ Hindlll molecular mass marker; 2, plasmids isolated from $L b$. brevis 925A. Each plasmid band was confirmed by Southern blot analysis using a DNA fragment from each plasmid as a probe (data not shown). C, Chromosome. (b, c) Physical map and gene organization of plasmids pLB925A01-04. Gene organization in the putative brevicin 925A gene cluster is also indicated in (c). The filled black arrows indicate the transcriptional regulator. 
to brevicin 925A, suggesting that the genes for bacteriocin production and immunity are on plasmid pLB925A04.

During the plasmid-curing trials, pLB925A04 was cured with high frequency $(\sim 55 \%)$, but the smaller plasmids had a tendency to be maintained in Lb. brevis $925 \mathrm{~A}$.

\section{Sequence analysis of pLB925A01-04}

We determined the entire nucleotide sequence of the four plasmids maintained in the strain 925A. pLB925A01-04 have molecular sizes of 1815, 3524, 8881 and $65037 \mathrm{bp}$, respectively. Fig. 2 shows the gene organization of each plasmid. The mean $\mathrm{G}+\mathrm{C}$ contents of pLB925A01-04 are $37.3,37.5,42.2$ and $40.8 \mathrm{~mol} \%$, respectively, whereas that of the Lb. brevis ATCC 367 chromosome is $46.2 \%$ (Makarova et al., 2006). All ORFs larger than 50 bp were compared against the protein database using the BLAST server as shown in Table 3.

The ORFs seen on each plasmid are annotated as follows.

(i) pLB925A01 and pLB925A02. Both plasmids may be replicated via a rolling-circle replication (RCR) mechanism. pLB925A01 has two genes, annotated repA and $\operatorname{copA}$, which are involved in plasmid replication. The repA gene product exhibits high similarity with the Rep protein from Lactobacillus helveticus ATCC 15009 plasmid pLH2 (Pridmore et al., 1994), and the copA gene product is similar to the RepA protein from $L b$. plantarum WCFS1 (van Kranenburg et al., 2005).

pLB925A02 has the sequence 5'-TTCTTCTTATCTTGATACTA-3' located upstream of repA. The sequence is homologous to the double-stranded origin $(d s o)$ of the pC194/pUB110-type RCR plasmid (Bouia et al., 1989; del Solar et al., 1998; Leer et al., 1992). The repA gene product is almost the same as the replication-associated protein from Lactobacillus casei A23 plasmid pSMA23 (accession no. DQ116709). Thus, pLB925A02 may belong to the pC194/ pUB110 family, but the plasmid control system has never been identified (del Solar et al., 1998).

(ii) pLB925A03. This plasmid contains eight ORFs, which consist of three genes (repA, repB and repC) for replication, three genes for mobilization and two unknown genes (Fig. 2b \& Table 3). Although the repC gene product is similar to a hypothetical protein that controls plasmid copy number of Lactobacillus paracasei subsp. paracasei NFBC 338 plasmid pCD01 (Desmond et al., 2005), it is truncated. While RepB also exhibits high similarity with the putative replication protein (ORF9) from pCD01 (Desmond et al., 2005), the ori sequence for repB is absent. Therefore, the repB and repC gene products might not be functional. The repA product exhibits high similarity $(88 \%)$ to the replication protein of pLJ42 from $L b$. plantarum (accession no. DQ099911). The upstream sequence of repA contains a $10 \mathrm{bp}$ direct repeat and a $22 \mathrm{bp}$ direct repeat, which suggests that it is similar to the
pUCL287-type replication origin (Desmond et al., 2005) (Fig. 3a).

(iii) pLB925A04. pLB925A04 has a putative ori downstream of repA (Fig. $3 b$ ), and the iteron region of this plasmid is similar to that of $\operatorname{pAM} \beta$-1-family plasmids (del Solar et al., 1998).

This plasmid seems to contain several genes that may be involved in brevicin 925A biosynthesis (Fig. 2c \& Table 3). As shown in Fig. 2(c), the predicted gene cluster contains the structural genes for bacteriocin biosynthesis (breB and bre C), transcriptional regulators (breD and bre G), an $\mathrm{ABC}$ transporter $(\mathrm{breH})$ and its accessory protein (breA). The deduced amino acid sequence of the N-terminal region of $\mathrm{BreB}$ is identical to the partial amino acid sequence KKKKKYTGPNYR from purified brevicin 925A, indicating that $b r e B$ is the structural gene for brevicin 925A. The deduced amino acid sequence of BreB is identical to that of PlnC in Lb. plantarum TMW1.25 (Ehrmann et al., 2000). The function of PlnC in Lb. plantarum TMW1.25 has not yet been elucidated. The deduced amino acid sequence of BreC was also identical to the amino acid sequence of the bacteriocin plantaricin $1.25 \beta$, which is encoded by $\operatorname{pln} B$ of Lb. plantarum TMW1.25 (Ehrmann et al., 2000; Remiger et al., 1999). Like breB, which is located just upstream of breC, $\operatorname{pln} C$ is located just upstream of $\operatorname{pn} B$ in TMW1.25 (Ehrmann et al., 2000). The organization of the structural genes for plantaricin biosynthesis $(p \ln C$ and $p \ln B$ ) appears to be similar to that for brevicin (breB and $b r e C$ ); however, the genes for an $\mathrm{ABC}$ transporter and transcriptional regulators, which are evident in the brevicin 925A biosynthetic gene cluster, are absent in Lb. plantarum TMW1.25 (Ehrmann et al., 2000). The gene products of breD and breG contain a helix-turn-helix DNA-binding motif (COG1476). breE, which displays no significant similarity in the BLAST search database, is co-transcribed with $b r e D$, a fact confirmed by RT-PCR analysis (data not shown).

\section{Construction of a shuttle vector for LAB and E. coli.}

To construct a shuttle vector for $\mathrm{LAB}$ and $E$. coli, which will be useful as a gene manipulation tool for LAB, we employed the replicon of pLB925A03. The shuttle vector, designated pLES003, consists of a replication origin from pLB925A03, repA, a ColE1 origin, the erythromycin resistance gene from vector $\mathrm{pH} 2515$ (Shimizu-Kadota et al., 1991), and the multi-cloning site from pUC19 (Fig. 4). We confirmed that the vector could be replicated in cells of $L b$. brevis, Lb. plantarum, Lb. helveticus and Enterococcus hirae (data not shown).

\section{Characterization of the breE gene product.}

A hydropathy plot of the breE gene product, constructed using the SOSUI program (http://bp.nuap.nagoya-u.ac.jp/ sosui), suggests that the putative protein has four trans- 
Table 3. Similarities of ORFs in plasmids pLB925A01-04

\begin{tabular}{|c|c|c|c|c|c|}
\hline Plasmid and gene & Location $^{\star}$ & Size (aa) & Best BLAST match (source) & $\begin{array}{c}\text { Protein } \\
\text { accession no. }\end{array}$ & $\begin{array}{l}\text { Identity (\% overlapping } \\
\text { amino acids) }\end{array}$ \\
\hline \multicolumn{6}{|l|}{ pLB925A01 } \\
\hline $\operatorname{cop} A$ & $845-1000$ & 51 & $\begin{array}{l}\text { Copy-number control protein (Lb. plantarum } \\
\text { WCFS1: pWCFS102) }\end{array}$ & YP_133711 & $68(50)$ \\
\hline repA & $1073-1765$ & 230 & $\begin{array}{l}\text { Plasmid replication protein ( Lb. helveticus } \\
\text { ATCC 15009: pLH2) }\end{array}$ & CAA57504 & $81(230)$ \\
\hline \multicolumn{6}{|l|}{ pLB925A02 } \\
\hline mobA & $55-1140$ & 361 & $\begin{array}{l}\text { Mobilization protein (Pediococcus pentosaceus } \\
\text { R64: pRS4) }\end{array}$ & CAI92903 & $72(365)$ \\
\hline \multicolumn{6}{|l|}{ pLB925A03 } \\
\hline repB & $555-16 \mathrm{C}$ & 179 & $\begin{array}{l}\text { Putative replication protein }(L b \text {. paracasei subsp. } \\
\text { paracasei NFBC 338: pCD01) }\end{array}$ & AAW81271 & $96(179)$ \\
\hline orf 2 & $1263-760 \mathrm{C}$ & 167 & $\begin{array}{l}\text { Hypothetical protein (Lb. paracasei subsp. } \\
\text { paracasei NFBC 338: pCD01) }\end{array}$ & AAW81289 & $99(161)$ \\
\hline orf 3 & $3433-1283 \mathrm{C}$ & 716 & YbfG (Bacillus subtilis subsp. subtilis 168) & CAB12014 & $38(697)$ \\
\hline repA & $4250-5173$ & 307 & RepA ( Lb. plantarum: pLJ42) & AAZ13604 & $85(306)$ \\
\hline$m o b C$ & $5872-6210$ & 112 & MobC (Lb. plantarum: pLJ42) & AAZ13605 & $97(112)$ \\
\hline$m o b A$ & $6189-7436$ & 415 & MobA (Lb. plantarum: pLJ42) & AAZ13606 & $74(445)$ \\
\hline $\begin{array}{l}\text { mobB } \\
\text { pLB925A04 }\end{array}$ & $7433-8101$ & 222 & MobB (Lb. plantarum: pLJ42) & AAZ13607 & $62(229)$ \\
\hline topA & $81-2198$ & 705 & $\begin{array}{l}\text { Hypothetical protein gbs0387 (Streptococcus } \\
\text { agalactiae NEM316) }\end{array}$ & NP_734855 & $33(588)$ \\
\hline orf 2 & $2200-2982$ & 260 & No hits & - & - \\
\hline$c l p A$ & $3003-4796$ & 597 & $\begin{array}{l}\text { Hypothetical protein gbs0388 (Streptococcus } \\
\text { agalactiae NEM316) }\end{array}$ & NP_734856 & $45(586)$ \\
\hline orf4 & $4862-5185$ & 107 & $\begin{array}{l}\text { Hypothetical membrane-spanning protein ( } L b . \\
\text { salivarius subsp. salivarius UCC118: pMP118) }\end{array}$ & YP_536707 & $31(98)$ \\
\hline orf5 & $5256-7427$ & 723 & $\begin{array}{l}\text { Hypothetical membrane associated protein ( } L b \text {. } \\
\text { salivarius subsp. salivarius UCC118: pMP118) }\end{array}$ & YP_536706 & $19(741)$ \\
\hline srtA & $8220-9059$ & 279 & Sortase $($ Lb. brevis ATCC 367$)$ & YP_794685 & $37(162)$ \\
\hline orf7 & $9085-9978$ & 297 & No hits & - & - \\
\hline orf8 & $10027-12378$ & 783 & $\begin{array}{l}\text { Hypothetical protein EfaeDRAFT_1901 } \\
\text { (Enterococcus faecium DO) }\end{array}$ & ZP_00603526 & $26(654)$ \\
\hline orf9 & $12915-13769$ & 284 & $\begin{array}{l}\text { Transposase, IS30 family (Pediococcus pentosa- } \\
\text { ceus ATCC 25745) }\end{array}$ & YP_804033 & $91(285)$ \\
\hline orf10 & $13983-14675$ & 230 & $\begin{array}{l}\text { Dihydrodipicolinate synthase/ } N \text {-acetylneurami- } \\
\text { nate lyase }(\text { Lb. casei ATCC } 334)\end{array}$ & YP_805579 & $60(217)$ \\
\hline orf11 & $14808-15491$ & 227 & Transposase ( Lb. casei ATCC 334) & YP_796441 & $69(227)$ \\
\hline orf12 & $15730-16431$ & 233 & $\begin{array}{l}\text { Conserved hypothetical protein (Enterococcus } \\
\text { faecium DO) }\end{array}$ & ZP_00603671 & $32(202)$ \\
\hline orf13 & $16989-17423$ & 144 & $\begin{array}{l}\text { Hypothetical protein OEOE_1493 (Oenococcus } \\
\text { oeni PSU-1) }\end{array}$ & YP_811017 & $44(134)$ \\
\hline orf14 & $19218-18379$ C & 279 & $\begin{array}{l}\text { Transposase, IS30 family ( Lb. brevis ATCC 367: } \\
\text { plasmid 2) }\end{array}$ & YP_796412 & $100(279)$ \\
\hline orf15 & 19640-20623 & 327 & $\begin{array}{l}\text { Hypothetical protein pRUM_p05 (Enterococcus } \\
\text { faecium U37: pRUM_p05) }\end{array}$ & NP_863148 & $24(302)$ \\
\hline orf16 & 20939-21556 & 205 & Recombinase (Enterococcus faecalis: pAM373) & NP_072000 & 49 (203) \\
\hline breA & $25140-24730 \mathrm{C}$ & 136 & $\begin{array}{l}\text { Transport accessory protein (Brochothrix cam- } \\
\text { pestris ATCC } 43754 \text { ) }\end{array}$ & AAC95141 & $31(130)$ \\
\hline breB & $25717-25938$ & 73 & Plantaricin $1.25 \gamma($ Lb. plantarum TMW1.25) & $2607194 \mathrm{~A}$ & $100(73)$ \\
\hline breC & $25970-26179$ & 69 & Plantaricin $1.25 \beta$ (Lb. plantarum TMW1.25) & CAA09476 & $100(69)$ \\
\hline$b r e D$ & $26436-26239 \mathrm{C}$ & 65 & Helix-turn-helix motif ( $L b$. reuteri $100-23$ ) & ZP_01273725 & $53(58)$ \\
\hline breE & $26944-26447$ C & 178 & $\begin{array}{l}\text { Hypothetical protein BA5499 (Bacillus anthracis } \\
\text { Ames) }\end{array}$ & NP_847659 & $29(164)$ \\
\hline orf 22 & 28304-27375 C & 309 & $\begin{array}{l}\text { Transposase, IS30 family (Pediococcus pentosa- } \\
\text { ceus ATCC 25745) }\end{array}$ & YP_804033 & $98(309)$ \\
\hline
\end{tabular}


Table 3. cont.

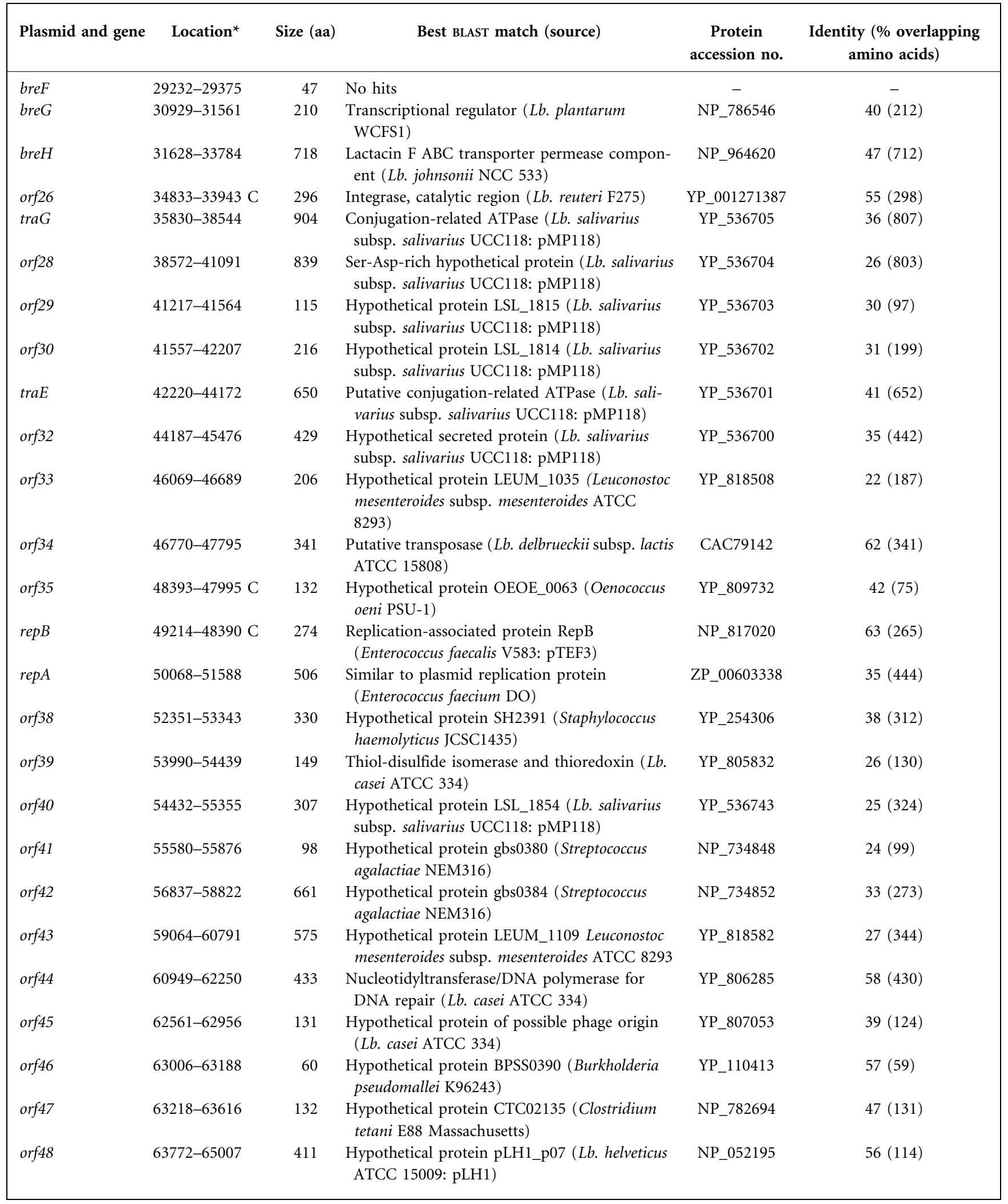

${ }^{*} \mathrm{C}$, Complementary sequence 
(a)

4011

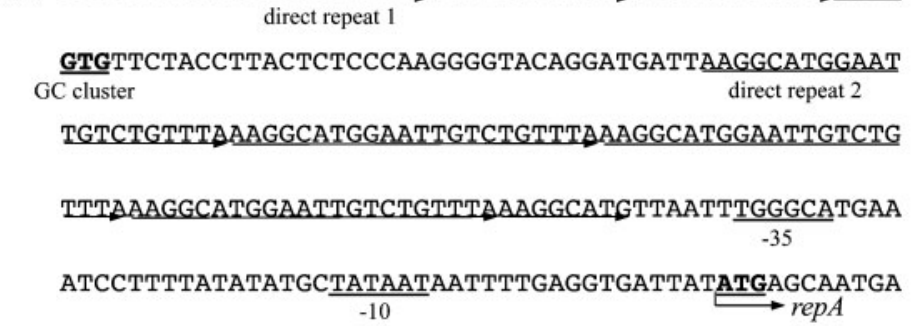

(b)

\section{CATGCGGCTTTTCAAGTGTATACATAACAGTTCCAAATGTTTTATT}

TTGCATTCATGTATACAGAATTTACATGTATARCTTAGTTTGCTTGT ATATATAGCGTAAAAGTAAATTAAATCTACAAAGAACAAATGTCTC

$\rightarrow$ TGAGACATATAAATTATGTGTAAACGGCGTATACATGCATACGCCG

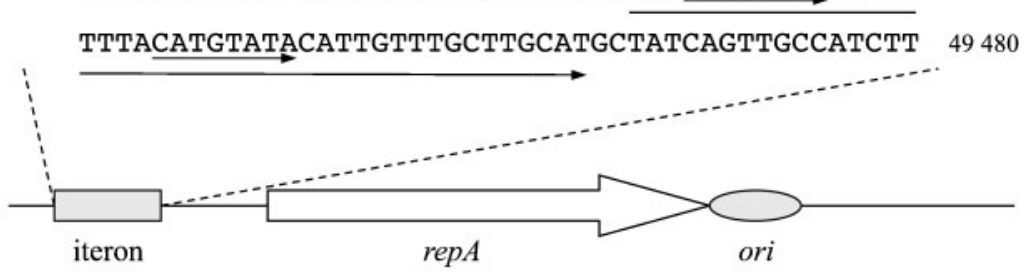

4260

\footnotetext{
Fig. 3. Proposed ori regions of plasmids pLB925A03 and 04. Single arrows indicate direct repeats. (a) Iteron region of pLB925A03. (b) Predicted ori, iteron and repA region in pLB925A04. The nucleotide sequence of the iteron is also shown.
}

membrane domains. To speculate a role for the gene product, a DNA fragment containing breE was inserted into pLES003 and introduced into a pLB925A04 plasmid-cured derivative of $L b$. brevis $925 \mathrm{~A}$, designated $L b$. brevis $925 \mathrm{~A}-$ $\Delta 02 / 03 / 04$. This strain, which is susceptible to brevicin $925 \mathrm{~A}$, harbours plasmid pLB925A01, but not pLB925A02-04. As shown in Fig. 5, the transformant acquired immunity to brevicin 925A, suggesting that the breE gene product is an immunity protein which functions as a self-resistant determinant in brevicin 925A-producing strains.

\section{DISCUSSION}

In this study we isolated a new bacteriocin from the culture broth of $L b$. brevis $925 \mathrm{~A}$ and determined the nucleotide sequence of four plasmids harboured in this strain.

A BLAST search for Rep proteins encoded by ORFs on plasmids harboured in $L b$. brevis 925A suggests that two types of plasmid are present with regard to replication: pLB925A01 and pLB925A02 use an RCR-type replication mechanism, whereas pLB925A03 and pLB925A04 use theta replication. pLB925A01-03 may not contain any significant functional genes, except for their cop, rep and mob genes (Fig. 2b). As listed in Table 3, pLB925A04 carries many ORFs other than those that constitute the bacteriocin-biosynthesizing gene cluster. However, most of the ORFs cannot be annotated. Interestingly, the srtA gene product exhibits similarity with sortase (Pfam PF04203), which is necessary for adhesion and expected to be a useful target for future antimicrobial agents (Mazmanian et al., 1999; Scott \& Zähner, 2006). However, comparative genomics of LAB carried out by Makarova et al. (2006) suggests that the sortase gene in Lb. brevis ATCC 367 is on the chromosome.

A new bacteriocin, brevicin 925A, was identified in $L b$. brevis $925 \mathrm{~A}$. It showed bacteriocin activity against Listeria monocytogenes and $S$. mutans, which cause food poisoning and dental caries, respectively. This polypeptide may be useful in preventative dental medicine, in addition to applications in food sanitation as a biopreservative. Brevicin 925A is encoded on pLB925A04 - both the structural gene $b r e B$ and the immunity gene breE were identified on the plasmid. The deduced amino acid sequence of BreB (=brevicin 925A) is identical to that of PlnC in Lb. plantarum TMW1.25 (Ehrmann et al., 2000). The function of PlnC has not been elucidated. Strain TMW1.25 has been reported to produce two bacteriocins, designated plantaricin $1.25 \alpha$ and $1.25 \beta$, but only the biosynthetic gene $p \ln B$ encoding plantaricin $1.25 \beta$ has been cloned (Ehrmann et al., 2000; Remiger et al., 1999). $p \ln B$ is located just downstream of $p \ln C$ in TMW1.25 (Ehrmann et al., 2000). Plantaricin 1.25 $\beta$, which corresponds to the breC gene product (BreC) of strain 925A, has been purified from $L b$. plantarum TMW1.25 (Remiger et al., 1999). However, the breC gene product could not be detected in the strain 925A culture supernatant. Although the precise mode of action of BreC has not yet been elucidated, it might interact with BreB to express bacteriocin activity. 


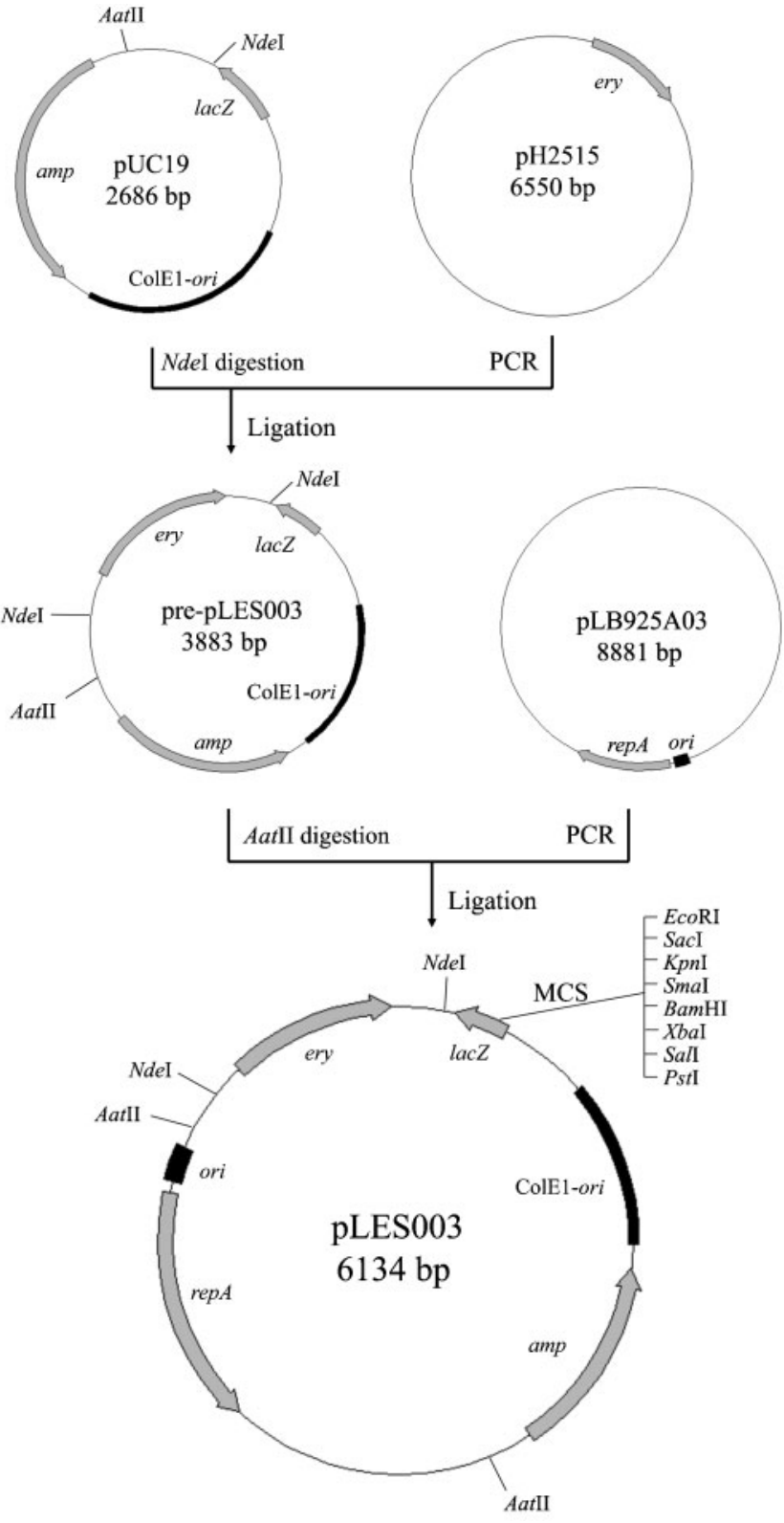

Fig. 4. Construction of shuttle vector pLES003. The Ndel and Aatll sites were used to construct the shuttle vector.

Until now, it has not been confirmed whether the plantaricin biosynthetic gene cluster is located on a plasmid or on the Lb. plantarum chromosome. Since the brevicin 925A gene cluster appeared to be located on the largest plasmid, pLB925A04, from the plasmid-curing and sequencing analyses, we transformed $L b$. brevis $925 \mathrm{~A}-\Delta 02 /$ 03/04 with pLB925A04. The transformant acquired both production of brevicin 925A and immunity to the bacteriocin. This indicates that the brevicin 925A biosynthetic gene cluster is indeed located on pLB925A04.

We speculate that the brevicin $925 \mathrm{~A}$ biosynthetic cluster is composed of eight ORFs (breA-H) on pLB925A04 (Fig. 2c).

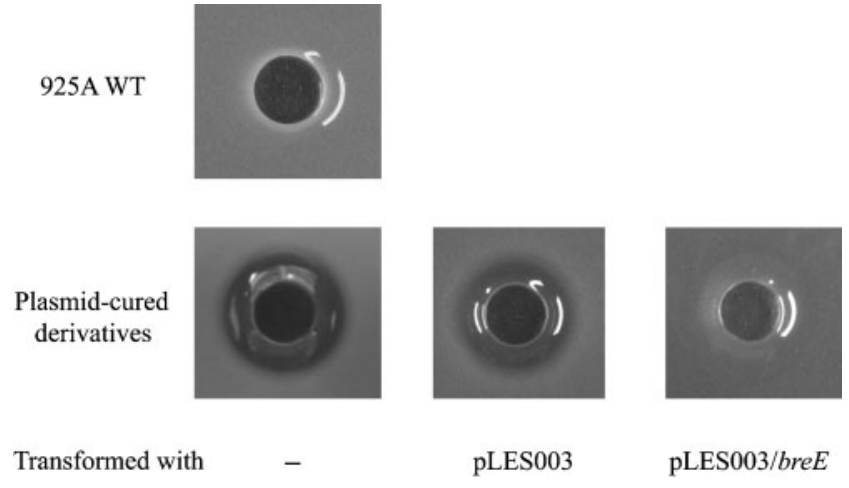

Fig. 5. Function of the bre $E$ gene product. The pLB925A04cured derivative of strain 925A transformed with pLES003 or pLES003/breE was grown on MRS-agar medium containing $5 \mu \mathrm{g}$ erythromycin $\mathrm{ml}^{-1}$. Growth of the plasmid-cured derivative and the same strain carrying pLES003 was inhibited by brevicin 925A, as shown by the inhibition zone. However, growth of the parental strain (WT) and the plasmid-cured derivative transformed with pLES003/breE were not inhibited by brevicin $925 \mathrm{~A}$.

As listed in Table 3, the breA gene product displays significant similarity with bacteriocin transport accessory proteins from Lb. plantarum (protein ID AAP83159, 28\%) and Streptococcus pneumoniae (EDT90159, 30\%). In general, an accessory protein, which is involved in the secretion of polypeptides, works in conjunction with a bacteriocin $\mathrm{ABC}$ transporter (Franke et al., 1999). In addition to the ABC transporter conserved domain, the breH gene product contains the N-terminal peptidase domain (Pfam PF03412) which recognizes and cleaves the bacteriocin precursors at a double-glycine site. Most non-lantibiotic bacteriocins are synthesized as precursor peptides with N-terminal leader extensions that are cleaved off during maturation (Franke et al., 1999). This motif is also found in the peptides predicted from $b r e B$ and $b r e C$. Since the $b r e E$ gene was not annotated by a BLAST search, we tried to introduce breE into a pLB925A04-deleted derivative, $L b$. brevis $925 \mathrm{~A}-\Delta 02 / 03 / 04$. As a result, the transformant was observed to acquire immunity to brevicin 925A (Fig. 5). We confirmed by RTPCR analysis that the expression of breF (not annotated by the BLAST search) is synchronized with the expression of seven other genes (data not shown). breF may therefore also play a significant role in bacteriocin biosynthesis.

It should be noted that to date, there has been no full characterization of the many genes essential for bacteriocin export, immunity and transcriptional regulation. Further functional analysis of the genes of the brevicin 925A biosynthetic gene cluster, including a mechanism that regulates the production of the bacteriocin and the synergistic effect of two bacteriocins, is ongoing.

To develop a plasmid vector as a tool for LAB gene manipulation and characterization of several genes in the brevicin 925A biosynthetic cluster, we generated a shuttle 
vector that replicates in both E. coli and LAB. Since RCR plasmids generally exhibit broad host-range replication properties at high copy number (Pérez-Arellano et al., 2001), at first we employed pLB925A01 for the construction of a shuttle vector. However, the resulting vector was not successfully maintained in E. coli. Next, we used another high-copy-number plasmid, pLB925A03, for vector construction (Fig. 4). The resulting vector, pLES003, replicated successfully in both E. coli and LAB such as Lb. plantarum, Lb. brevis, Lb. helveticus, Lb. hilgardii and Enterococcus hirae. breE inserted into pLES003 also conferred immunity to brevicin $925 \mathrm{~A}$ in the bacteriocinsusceptible host cell (Fig. 5). This shuttle vector will be useful for functional analysis of ORFs located in the brevicin 925A biosynthetic gene cluster.

\section{ACKNOWLEDGEMENTS}

We are grateful to $\mathrm{Mr}$ Shinya Yamauchi for technical assistance, Hiroshima Prefectural Food Technology Research Center, Japan. This work was supported by Hiroshima Biocluster (Cooperative Link of Unique Science and Technology for Economy Revitalization), Japan (M.S.). We wish to thank the Research Center for Molecular Medicine, Faculty of Medicine, and the Analysis Center of Life Science, Hiroshima University for the use of their facilities.

\section{REFERENCES}

Adolfsson, O., Meydani, S. N. \& Russell, R. M. (2004). Yogurt and gut function. Am J Clin Nutr 80, 245-256.

Alegre, M. T., Rodriguez, M. C. \& Mesas, J. M. (2004). Transformation of Lactobacillus plantarum by electroporation with in vitro modified plasmid DNA. FEMS Microbiol Lett 241, 73-77.

Altschul, S. F., Gish, W., Miller, W., Myers, E. W. \& Lipman, D. J. (1990). Basic local alignment search tool. J Mol Biol 215, 403-410.

Bouia, A., Bringel, F., Frey, L., Kammerer, B., Belarbi, A., Guyonvarch, A. \& Hubert, J. C. (1989). Structural organization of pLP1, a cryptic plasmid from Lactobacillus plantarum CCM 1904. Plasmid 22, 185-192.

Chin, S. C., Abdullah, N., Siang, T. W. \& Wan, H. Y. (2005). Plasmid profiling and curing of Lactobacillus strains isolated from the gastrointestinal tract of chicken. J Microbiol 43, 251-256.

Cross, M. L., Stevenson, L. M. \& Gill, H. S. (2001). Anti-allergy properties of fermented foods: an important immunoregulatory mechanism of lactic acid bacteria? Int Immunopharmacol 1, 891-901.

del Solar, G., Giraldo, R., Ruiz-Echevarría, M. J., Espinosa, M. \& Díaz-Orejas, R. (1998). Replication and control of circular bacterial plasmids. Microbiol Mol Biol Rev 62, 434-464.

Desmond, C., Ross, R. P., Fitzgerald, G. \& Stanton, C. (2005). Sequence analysis of the plasmid genome of the probiotic strain Lactobacillus paracasei NFBC338 which includes the plasmids pCD01 and pCD02. Plasmid 54, 160-175.

Dunny, G. M., Lee, L. N. \& LeBlanc, D. J. (1991). Improved electroporation and cloning vector system for Gram-positive bacteria. Appl Environ Microbiol 57, 1194-1201.

Ehrmann, M. A., Remiger, A., Eijsink, V. G. H. \& Vogel, R. F. (2000). A gene cluster encoding plantaricin $1.25 \beta$ and other bacteriocin-like peptides in Lactobacillus plantarum TMW1.25. Biochim Biophys Acta 1490, 355-361.
Franke, C. M., Tiemersma, J., Venema, G. \& Kok, J. (1999). Membrane topology of the lactococcal bacteriocin ATP-binding cassette transporter protein LcnC: involvement of $\mathrm{LcnC}$ in lactococcin a maturation. J Biol Chem 274, 8484-8490.

Guarner, F. \& Schaafsma, G. J. (1998). Probiotics. Int J Food Microbiol 39, 237-238.

Heyman, M. (2000). Effect of lactic acid bacteria on diarrheal diseases. J Am Coll Nutr 19, 137S-146S.

Hiraishi, A. (1992). Direct automated sequencing of $16 \mathrm{~S}$ rDNA amplified by polymerase chain reaction from bacterial cultures without DNA purification. Lett Appl Microbiol 15, 210-213.

Klaenhammer, T. R. (1988). Bacteriocins of lactic acid bacteria. Biochimie 70, 337-349.

Lane, D. J. (1991). 16S/23S sequencing. In Nucleic Acid Techniques in Bacterial Systematics. Edited by E. Stackebrandt \& M. Goodfellow. Chichester: Wiley.

Lavermicocca, P., Valerio, F., Linigro, S. L., Angelis, M. D., Morelli, L., Callegari, M. L., Rizzello, C. G. \& Visconti, A. (2005). Study of adhesion and survival of lactobacilli and bifidobacteria on table olives with the aim of formulating a new probiotic food. Appl Environ Microbiol 71, 4233-4240.

Leer, R. J., van Luijk, N., Posno, M. \& Pouwels, P. H. (1992). Structural and functional analysis of two cryptic plasmids from Lactobacillus pentosus MD353 and Lactobacillus plantarum ATCC 8014. Mol Gen Genet 234, 265-274.

Makarova, K., Slesarev, A., Wolf, Y., Sorokin, A., Mirkin, B., Koonin, E., Pavlov, A., Pavlova, N., Karamychev, V. \& other authors (2006). Comparative genomics of the lactic acid bacteria. Proc Natl Acad Sci U S A 103, 15611-15616.

Mazmanian, S. K., Liu, G., Ton-That, H. \& Schneewind, O. (1999). Staphylococcus aureus sortase, an enzyme that anchors surface proteins to the cell wall. Science 285, 760-763.

Meydani, S. N. \& Ha, W. K. (2000). Immunologic effects of yogurt. Am J Clin Nutr 71, 861-872.

Okada, S. (2002). The world of plant origin lactic acid bacteria. Jpn J Lactic Acid Bacteria 13, 23-26.

Pérez-Arellano, I., Zúñiga, M. \& Pérez-Martínez, G. (2001). Construction of compatible wide-host-range shuttle vectors for lactic acid bacteria and Escherichia coli. Plasmid 46, 106-116.

Pridmore, R. D., Stefanova, T. \& Mollet, B. (1994). Cryptic plasmids from Lactobacillus helveticus and their evolutionary relationship. FEMS Microbiol Lett 124, 301-305.

Remiger, A., Eijsink, V. G., Ehrmann, M. A., Sletten, K., Nes, I. F. \& Vogel, R. F. (1999). Purification and partial amino acid sequence of plantaricin $1.25 \alpha$ and $1.25 \beta$, two bacteriocins produced by Lactobacillus plantarum TMW1.25. J Appl Microbiol 86, 1053-1058.

Sambrook, J. \& Russell, D. W. (2001). Molecular Cloning: a Laboratory Manual, 3rd edn. Cold Spring Harbor, NY: Cold Spring Harbor Laboratory.

Sambrook, J., Fritsch, E. F. \& Maniatis, T. (1989). Molecular Cloning: a Laboratory Manual, 2nd edn. Cold Spring Harbor, NY: Cold Spring Harbor Laboratory.

Scott, J. R. \& Zähner, D. (2006). Pili with strong attachments: Grampositive bacteria do it differently. Mol Microbiol 62, 320-330.

Shimizu-Kadota, M., Shibahara-Sone, H. \& Ishiwa, H. (1991). Shuttle plasmid vectors for Lactobacillus casei and Escherichia coli with a minus origin. Appl Environ Microbiol 57, 3292-3300.

van Hylckama Vlieg, J. E. T., Rademaker, J. L. W., Bachmann, H., Molenaar, D., Kelly, W. J. \& Siezen, R. J. (2006). Natural diversity and adaptive responses of Lactococcus lactis. Curr Opin Biotechnol 17, 183-190. 
van Kranenburg, R., Golic, N., Bongers, R., Leer, R. J., de Vos, W. M., Siezen, R. J. \& Kleerebezem, M. (2005). Functional analysis of three plasmids from Lactobacillus plantarum. Appl Environ Microbiol 71, 1223-1230.

van Reenen, C. A., Dicks, L. M. \& Chikindas, M. L. (1998). Isolation, purification and partial characterization of plantaricin 423, a bacteriocin produced by Lactobacillus plantarum. J Appl Microbiol 84, 1131-1137.

Weisburg, W., Barns, S., Pelletier, D. \& Lane, D. (1991). 16S ribosomal DNA amplification for phylogenetic study. J Bacteriol 173, 697-703.

Edited by: K. E. Weaver 